\author{
REVIEW OF EUROPEAN AND COMPARATIVE LAW \\ VOLUME XLVII \\ YEAR 2021, ISSUE 4 pp. 27-47 \\ DOI: https://doi.org/10.31743/recl.12847
}

\title{
ADMINISTRATION OF THE ESTATE UNDER REGULATION (EU) NO. 650/2012
}

Jacek Górecki*

\begin{abstract}
In the period between the deceased person's death and division of assets in the deceased person's estate among the heirs, an essential matter is administration of the estate. Persons exercising such administration should have adequate competences allowing them to perform factual and legal acts in relation to assets in the succession estate. The range of such persons and the scope of their competences differ in specific Member States of the EU. The law applicable to the administration of the estate, as well as other matters relating to succession, is currently designated by the Regulation (EU) No. 650/2012. This article is devoted to an analysis of the provisions of that Regulation on the administration of the estate. In addition, the article discusses the issue of qualifying the institution of succession administration as applicable in Poland with regard to an enterprise belonging to the succession estate. As a result of the investigations made, it can be concluded that administration of the estate is governed by the law applicable to the entirety of succession matters (lex successionis). This is the case also in respect of the succession administration recently introduced in Poland. Grounds for a different treatment of the succession administration cannot be found in Art. 30 of Regulation (EU) No. 650/2012.
\end{abstract}

Keywords: succession, administration of the estate, executor of testament, succession administration

Prof. Dr. habil. Jacek Górecki, Professor, Faculty of Law and Administration, University of Silesia in Katowice; correspondence address: Bankowa 11B, 40-007 Katowice, Poland; e-mail: jacek.gorecki@us.edu.pl; https://orcid.org/0000-0002-0812-1654. 


\section{GENERAL REMARKS}

Conflict-of-law aspects of succession are currently regulated in Poland and other Member States of the EU (except for Denmark and Ireland) in Regulation (EU) No. 650/2012 ${ }^{1}$. The law applicable to the total of succession matters (lex successionis) is designated predominantly in Arts. 21 and $22 \mathrm{ESR}^{2}$. Under Art. $21 \mathrm{ESR}$, in principle, lex successionis is the law of the country where the deceased person had his habitual residence at the time of death. Where, by way of exception, it is clear from all the circumstances of the case that, at the time of death, the deceased was manifestly more closely connected with a State other than the State of his last habitual residence, the law applicable to the succession shall be the law of that other State. However, under Art. 22 ESR, a person may choose as the law to govern his succession as a whole the law of the State whose nationality he possesses at the time of making the choice or at the time of death. A person possessing multiple nationalities may choose the law of any of the States whose nationality he possesses at the time of making the choice or at the time of death. The choice must be made expressly in a declaration in the form of a disposition of property upon death or must be demonstrated by the terms of such a disposition.

1 Regulation (EU) No. 650/2012 of the European Parliament and of the Council of 4 July 2012 on jurisdiction, applicable law, recognition and enforcement of decisions and acceptance and enforcement of authentic instruments in matters of succession and on the creation of a European Certificate of Succession, OJ 2012 No. L201, 27 July 2012, p. 107 et seq. Hereinafter referred to as ESR.

2 See Constanze Fischer-Czermak, "Anwendbares Recht," in Europäische Erbrechtsverordnung, eds. Martin Schauer and Elisabeth Scheuba (Wien: Manz, 2012), 43 et seq.; Paul Lagarde, "Applicable Law," in EU Regulation on Succession and Wills. Commentary, eds. Ulf Bergquist, Domenico Damascelli, Richard Frimson, Paul Lagarde, Felix Odersky, and Barbara Reinhartz (Köln: Verlag Dr. Otto Schmidt KG, 2015), 120 et seq.; Anna Wieczorek, "Ustalenie prawa właściwego w świetle rozporządzenia spadkowego nr 650/2012," Problemy Prawa Prywatnego Międzynarodowego 21 (2017): 74 et seq; Maksymilian Pazdan, in Prawo prywatne międzynarodowe. Komentarz, ed. Maksymilian Pazdan (Warsaw: C.H. Beck, 2018), 1162 et seq. and further literature cited therein. 


\section{LAW APPLICABLE TO THE ADMINISTRATION OF THE ESTATE UNDER REGULATION (EU) NO. 650/2012}

In Member States other solutions have been adopted in respect of the assumption of assets in the succession estate by heirs ${ }^{3}$. Most often, the heirs themselves may administrate the estate upon the deceased person's death, however, one of the alternative solutions is the obligation to appoint an administrator to administrate the estate after the deceased person's death and only then to transfer the estate's assets to heirs ${ }^{4}$. Moreover, in many countries it is admissible to appoint an executor of testament entitled to administer the succession estate upon the testator's death. However, the powers of such executor of testament have been defined differently in those countries, as well as the executor's appointment and recall, or the scope of the executor's discretion regarding the choice of administrator and designation of the administrator's rights and obligations.

In the context of the dissimilarities signalled above, a need arises to determine the law applicable to the administration of the estate upon the deceased person's death. Under Art. 23 letter f ESR, the law applicable to the succession governs, among others, the rights of heirs, testament

3 See Piotr Stec, in Unijne rozporzadzenie spadkowe Nr 650/2012, ed. Mariusz Załucki (Warsaw: C.H. Beck, 2018), 225; Gianluca Contaldi, "Special Rules on the Appointment and Powers of an Administrator of the Estate in Certain Situations," in The EU Succession Regulation. A Commentary, eds. Alfonso-Luis Calvo Caravaca, Angelo Davi, and Heinz-Peter Mansel (Cambridge: Cambridge University Press, 2016), 419-420; Maksymilian Pazdan, "Zarząd sukcesyjny - aspekty kolizyjnoprawne," in Prawo handlowe. Między teoria, praktyką a orzecznictwem. Ksiega jubileuszowa dedykowana Profesorowi Januszowi A. Strzępce, eds. Ewa Zielińska, Piotr Pinior, Paweł Relidzyński, Wojciech Wyrzykowski, and Mateusz Żaba (Warsaw: C.H. Beck, 2019), 71 and further literature cited therein.

4 For more, see Agata Kozioł, "System administracji spadku w porządkach prawnych państw kręgu anglosaskiego,” Rejent 2 (2006): 119 et seq.; Konrad Osajda, Ustanowienie spadkobiercy $w$ testamencie $w$ systemach prawnych common law i civil law (Warsaw: C.H. Beck, 2009), 236 et seq. 
executors ${ }^{5}$ or other administrators of the estate ${ }^{6}$, especially in relation to the sale of property and payment of creditors, without detriment to the rights referred to in Art. 29(2) and (3) ESR.

Article 23 letter $\mathrm{f}$ ESR decides that administration of the succession estate is governed by the law applicable to the succession irrespective of whether the estate is administered by heirs, executor of testament or other administrators of the estate ${ }^{8}$. Persons administering the estate may perform factual and legal acts in relation to assets in the estate and ${ }^{9}$ in particular, they may dispose of the assets or pay succession creditors (pay debts belonging to the estate). Finally, the cited provision lays down that, in respect of administration of the estate, the award and exercise of the powers referred to in Article 29(2) and (3) ESR are regulated differently ${ }^{10}$.

5 As regards the scope of the law applicable to the succession law in respect of a testament executor, see Maksymilian Pazdan, "O rozgraniczeniu statutów i wsysaniu regulacji prawnej (na przykładzie prawa stosowanego do oceny różnych aspektów powołania i funkcjonowania wykonawcy testamentu i zarządcy sukcesyjnego przedsiębiorstwem)," Problemy Prawa Prywatnego Międzynarodowego 27 (2021): 163-164.

6 By the term administrator of the estate, one should understand any person to whom the law applicable to the succession grants competences to administer the estate. See Dirk Looschelders, "EuErbVO," in Nomos Kommentar. Band 6. Rom-Verordnungen, eds. Rainer Hüßtege and Heinz-Peter Mansel (Baden Baden: Nomos, 2015), 925. Such category includes also a succession administrator, who will be discussed below.

Moreover, under Art. 75(3) ESR, the Regulation does not preclude application of the Convention of 19 November 1934 between Denmark, Finland, Iceland, Norway and Sweden comprising private international law provisions on succession, wills and estate administration, as revised by the intergovernmental agreement between those States of 1 June 2012, by the Member States which are parties thereto, among others, in so far as the Convention provides for procedural aspects of administering the estate, as specified in the Convention, and assistance in that regard provided by the authorities of the State-Parties of the Convention.

8 See recital 42.

9 However, it must be emphasized that the contents of the estate do not depend on the law applicable to the succession. The circumstance if a given asset of the deceased person is included in that person's succession estate is decided by the law applicable to the given asset. For more, see Pazdan, in "Prawo prywatne," 1181.

10 They were introduced in ESR because of the solutions adopted in the United Kingdom and Ireland. However, neither of these countries finally adopted the Regulation (EU) No. 650/2012. See recital 82 and Contaldi, in "The EU Succession," 421 et seq. 
The specific scope of competences of persons administering the estate is defined in the law applicable to the succession. It also resolves in respect of the admissibility and procedures for appointing ${ }^{11}$ and recalling the administrator, qualifications required to perform that function, the legal relationship between the administrator and other parties (especially heirs), and possible liability of the administrator vis-a-vis such parties. Moreover, the law applicable to the succession resolves about the scope of autonomy of will afforded both to the testator in the determination of the administrator's rights and obligations and to the administrator in the exercise of the rights granted to the administrator, including the possibility to surrender administration ${ }^{12}$. Lex successionis decides as well about the duration of the estate's administration and expiry of the rights afforded to persons exercising such administration. Considering the scope of the law applicable to the succession, as specified in Art. 23 ESR, such administration can be exercised, at the latest, until the completion of full division of the succession estate.

Under the provision of Art 29(1) ESR, where the appointment of an administrator is mandatory ${ }^{13}$ or mandatory upon request under the law of the Member State ${ }^{14}$ whose courts have jurisdiction to rule on the succession pursuant to the Regulation and the law applicable to the succession is a foreign law, the courts of that Member State may, when seised, appoint one or more administrators of the estate under their own law (lex fori), subject to the conditions laid down below ${ }^{15}$. As a result, in such

11 However, if the administrator of the estate is appointed under a testament or other disposition of property upon death, the substantive and formal validity of such disposition is assessed according to the law designated by separate conflict-of-law rules. See Pazdan, "O rozgraniczeniu," 167.

12 See Pazdan, "O rozgraniczeniu," 163-164.

13 Stec, in "Unijne rozporządzenie," 227, argues that Art. 29 ESR should also apply when the appointment of administrator is not compulsory but belongs to the court's competences as a part of discretionary judicial powers. In the light of the above, it should apply also when the court appoints the administrator as needed. See also Art. $666 \$ 1$ of the Polish Code of Civil Procedure, (consolidated text, Journal of Laws 2021, item 1805, as amended) on the appointment of curator of the estate.

14 See Łukasz Żarnowiec, Wptyw statutu rzeczowego na rozstrzyganie spraw spadkowych - na styku statutów (Warsaw: C.H. Beck, 2018), 232 et seq.

15 Lagarde, in "EU Regulation," 161 et seq. 
case, contrary to the provision of Art 23 letter $\mathrm{fESR}$, the administrator of the estate is appointed under the law of the court adjudicating in a given succession case. The discussed provision appeared in ESR because the rules of jurisdiction included in the Regulation may, in some cases, lead to a situation in which the court competent to decide a given succession case does not apply its own but foreign law ${ }^{16}$. When such situation is the case in a Member State whose law introduces an obligation to appoint an administrator of the estate (ex officio or upon request) ${ }^{17}$, the Regulation permits that courts of that Member State, when seised, may appoint one or more administrators in accordance with their own law ${ }^{18}$. However, this requires consideration of the circumstances laid down in Art. 29 ESR ${ }^{19}$.

The party appointed in the first place as the administrator is a person entitled to execute the deceased person's testament or to administer the deceased person's estate under the law applicable to the succession. This can be, for example, an executor of testament appointed by the testator or one of the heirs. If the person appointed as administrator is an heir, such heir should have the powers to administer the estate as afforded to heirs under the law applicable to the succession.

If lex successionis does not provide for a possibility of the estate being administered by a party other than beneficiary (heir or legatee), the court of the Member State in which the administrator is to be appointed may appoint a third-party administrator under its own law (lex fori) if the provisions of the court's own law so require, or in case of a serious conflict of interests between the beneficiaries or between the beneficiaries and creditors

16 This can happen when court jurisdiction is based on the connecting factor of the deceased person's habitual residence at the time of that person's death (Art. 4 ESR) and the law applicable to the succession is designated under the choice of law (Art. 22 ESR), or when the court's jurisdiction is based on Art. 10 or 11 ESR. See Looschelders, in "Nomos Kommentar," 951.

17 Such provisions apply in Cyprus, in Finland and in Sweden. The qualification of the solutions adopted in Austria and Germany is disputable. See Contaldi, in "The EU Succession," 424-425; Marcin Margoński, in Komentarze Prawa Prywatnego, T. VI B, Prawo $i$ postępowanie spadkowe. Komentarz, ed. Konrad Osajda (Warsaw: C.H. Beck, 2018), 66; Looschelders, in "Nomos Kommentar," 925-926, 951 and further statements cited therein.

\footnotetext{
18 See Recital 44.

19 See Pazdan, "Zarząd sukcesyjny," 72.
} 
or other parties who have guaranteed the deceased person's debts ${ }^{20}$, or in case of disagreement among the beneficiaries about the administration of the estate, or when the administration of the estate is complicated, bearing in mind the nature of its assets. However, if a testator has appointed an executor of testament, such person may not be deprived of his powers unless lex successionis allows for such person's recall ${ }^{21}$.

An administrator appointed as specified above is the only person entitled to exercise the powers referred to in Art 29(2) or (3) ESR. Under those provisions, a person appointed as administrator exercises the powers to administer the estate, as may be exercised under the law applicable to the succession. The court appointing the administrator may define the conditions of exercise of the administrator's powers in accordance with that law.

When lex successionis does not provide for sufficient powers to secure assets in the succession estate or to protect rights of creditors or other persons who have guaranteed the deceased person's debts, the court appointing the administrator may permit that the administrator supplementarily exercises the powers envisaged for that purpose in the provisions of law of the court's Member State (lex fori), and may specify, in the court's decision, the terms of exercising such powers according to the law of that Member State. However, in performance of such supplementing powers, the administrator must follow provisions of the law applicable to the succession on the transfer of title to the estate, liability for succession debts, beneficiary rights, including also, as the case may be, the right to accept or reject succession, and the rights of executor of the deceased person's testament. In consequence, acts performed by the administrator may also cover a transfer of the title to assets in the estate or payment of debts, but only when lex successionis so permits.

If, under the law applicable to the succession, appointment of a third-party administrator leads to a change of the heirs' liability for succession debts, such change should be respected. The supplementary

20 This refers not only to guarantors but also to other parties liable, beside heirs, for the deceased person's debts, e.g., persons who have provided guarantees on behalf of the deceased or joined a debt incurred by the deceased. See Looschelders, in "Nomos Kommentar," 952.

21 See Recital 43 in fine. 
powers exercised by the administrator may, for instance, cover preparing an inventory of assets and debts belonging to the estate, notifying creditors about the opening of succession, calling on creditors to submit their claims, or taking any interim steps, including precautionary measures, for the purpose of preserving the assets in the estate ${ }^{22}$.

Regardless of the above, the court appointing one or more administrators under Art. 29(1) ESR may, as an exception, in situations when the law applicable to the succession is the law of a third country ${ }^{23}$, decide to grant to such administrators all administrative powers as provided for in the law of the Member State in which those administrators are appointed (lex fori). However, in exercise of such powers, the administrators must respect, in particular, the specification of beneficiaries and their succession rights, including the right to a reserved share or claims against the succession estate or heirs as per the law applicable to the succession.

\section{PROOF OF THE STATUS OF ADMINISTRATOR OF THE ESTATE}

In order to perform the rights relating to the administration of an estate located in different Member States, the executor of testament or another administrator of the estate should hold an appropriate document certifying the administrator's status. Such document may be, in the first place, the European Certificate of Succession (hereinafter: Certificate) as referred to in Art. 62 et seq. ESR ${ }^{24}$.

22 See Recital 44 and Lagarde, in "EU Regulation,” 164.

23 Third countries are countries in which ESR does not apply, including Denmark and Ireland.

24 For more on the European Certificate of Succession, see Jacek Górecki, "Europejskie poświadczenie spadkowe - nowy sposób potwierdzania praw do majątku spadkowego," Rejent 9 (2015): 9 et seq.; Bernhard Kreße, "Creation of a European Certificate of Succession," in The EU Succession Regulation. A Commentary, eds. Alfonso-Luis Calvo Caravaca, Angelo Davi, and Heinz-Peter Mansel (Cambridge: Cambridge University Press, 2016), 673 et seq.; Mariusz Załucki, in Unijne rozporzadzenie spadkowe Nr 650/2012. Komentarz, ed. Mariusz Załucki (Warsaw: C.H. Beck, 2018), 334 et seq.; Andreas Köhler, in Internationales Erbrecht, eds. Walter Gierl, Andreas Köhler, Ludwig Kroiß, and Harald Wilsch (Baden Baden: Nomos, 2020), 138 et seq. 
Under Art. 63 ESR, such Certificate is intended for use not only by heirs or legatees but also executors of testaments or administrators of the estate who need to prove, in another Member State, their status to exercise their rights as executors of testaments or administrators of the estate ${ }^{25}$.

Under Art 65 ESR, the Certificate is issued, among others, upon application by an executor of testament or administrator of the estate. In such situations, the application should indicate the grounds on which the applicant claims to be entitled to execute the deceased person's testament or administrate the deceased person's estate. When considering the application, if needed, in order to establish the facts to be certified, the authority issuing the Certificate hears the executor of testament or administrator of the estate (Art. 66(4) ESR).

In the Certificate, the authority should include, among others, information on the circumstances giving rise to the rights or entitlements of testament executors or administrators of the estate (Art. 68 letter $j$ ESR) and point to the entitlements held by the testament executor or administrator of the estate and restrictions on such entitlements under the law applicable to the succession or disposition of property upon death (Art. 68 letter o ESR).

Under Art 69(2), second sentence, ESR, it is presumed that the person named in the Certificate as the executor of testament or administrator of the estate has the status indicated in the Certificate or has the rights or entitlements specified in the Certificate without any conditions or restrictions on such rights or entitlements, otherwise than specified in the Certificate's content. Moreover, under Art. 69(3) ESR, the executor of testament or administrator of the estate is also covered by the presumption that any person who, acting on the basis of the information certified in a Certificate, makes payments or passes on property to a person mentioned in the Certificate as authorised to accept payment or property shall be considered to have transacted with a person with authority to accept payment or property, unless he knows that the contents of the Certificate are not accurate or is unaware of such inaccuracy due to gross negligence.

25 See Bernhard Kreese, "Purpose of the Certificate," in The EU Succession Regulation. A Commentary, eds. Alfonso-Luis Calvo Caravaca, Angelo Davi, and Heinz-Peter Mansel (Cambridge: Cambridge University Press, 2016), 692-694. 
Where an executor of testament or administrator of the estate mentioned in the Certificate as a person authorised to dispose of succession property disposes of such property in favour of another person, that other person shall, if acting on the basis of the information certified in the Certificate, be considered to have transacted with a person with authority to dispose of the property concerned, unless he knows that the contents of the Certificate are not accurate or is unaware of such inaccuracy due to gross negligence (art. 69(4) ESR) ${ }^{26}$.

Apart from the Certificate, a document certifying the status of administrator of the estate may be a court ruling appointing the administrator or an official document in which an official certifies that the estate is administered by the administrator. Rulings delivered in such cases in Member States of the EU will be governed by Art 39 et seq. ESR on their recognition in other Member States without the need for any special proceedings ${ }^{27}$. On the other hand, in relation to official documents certifying the status of administrator of the estate, Art. 59 ESR will apply ${ }^{28}$. Such document may be, for example, a certificate of appointment of an executor of testament $\mathrm{t}^{29}$.

26 For more on the consequences of issuing the Certificate, see Carl Friedrich Nordmeier, in Nomos Kommentar. Band 6. Rom-Verordnungen, eds. Rainer Hüßtege, Heinz-Peter Mansel (Baden Baden: Nomos, 2015), 1079 et seq.; Barbara Reinhartz, "European Certificate of Succession," in EU Regulation on Succession and Wills. Commentary, eds. Ulf Bergquist, Domenico Damascelli, Richard Frimson, Paul Lagarde, Felix Odersky, and Barbara Reinhartz (Köln: Verlag Dr. Otto Schmidt KG, 2015), 283 et seq.; Christine Budzikiewicz, "Effects of the Certificate," in The EU Succession Regulation. A Commentary, eds. Alfonso-Luis Calvo Caravaca, Angelo Davi, and Heinz-Peter Mansel (Cambridge: Cambridge University Press, 2016), 770 et seq.; Köhler, in "Internationales Erbrecht," $145-146$.

27 See Elena D'Alessandro, "Staying of Recognition Proceedings," in The EU Succession Regulation. A Commentary, eds. Alfonso-Luis Calvo Caravaca, Angelo Davi, Heinz-Peter Mansel (Cambridge: Cambridge University Press, 2016), 563 et seq.

28 For more, see Heinz-Peter Mansel, "Acceptance of Authentic Instruments," in The EU Succession Regulation. A Commentary, eds. Alfonso-Luis Calvo Caravaca, Angelo Davi, and Heinz-Peter Mansel (Cambridge: Cambridge University Press, 2016), 625 et seq.; Jakub Biernat, in Unijne rozporzadzenie spadkowe $\mathrm{Nr}$ 650/2012. Komentarz, ed. Mariusz Załucki (Warsaw: C.H. Beck, 2018), 327 et seq.

29 See Art. 665 of the Polish Code of Civil Procedure. 


\section{LAW APPLICABLE TO THE APPOINTMENT OF A SUCCESSION ADMINISTRATOR}

Under Art. 1 of the Polish Act on succession administration of a natural person's enterprise and other facilitations relating to the succession of enterprises $^{30}$, the Act governs the terms of temporary administration of an enterprise upon death of an entrepreneur who conducted business activities on his own behalf under an entry in the Central Registry and Information about Business Activity, ${ }^{31}$ and continuation of business activities carried on using that person's enterprise, referred to, in further provisions of the cited Act, as enterprise in succession.

A basic question that arises in the conflict-of-law analysis of the institution of succession administration, as introduced by that Act, is the decision about the law applicable to the appointment of a succession administrator and his exercise of succession administration. As pointed out above, under Art. 23 letter f ESR, the powers of administrators of the estate are governed by lex successionis. This means that the provisions of the Act on the administration of an enterprise in succession should apply only when

30 Consolidated text, Journal of Laws 2021, item 170. Hereinafter cited as the Act. For more on succession administration, see Tomasz Szczurowski, "Zarząd sukcesyjny przedsiębiorstwem w spadku," Przegląd Ustawodawstwa Gospodarczego 11 (2018): 31 et seq.; Jerzy Bieluk, Ustawa o zarzadzie sukcesyjnym przedsiębiorstwem osoby fizycznej. Komentarz (Warsaw: C.H. Beck, 2019), passim; Rafał Blicharz, Zarzad sukcesyjny przedsiębiorstwem w spadku (Warsaw: Difin, 2019), passim. The legal status of the succession administrator is discussed by: Maksymilian Pazdan, "Zarządca sukcesyjny a wykonawca testamentu," in Ius est ars boni et aequi. Ksiega pamiątkowa dedykowana Profesorowi Józefowi Frąckowiakowi, eds. Anna Dańko-Roesler, Marek Leśniak, Maciej Skory, and Bogusław Sołtys (Wrocław: Stowarzyszenie Notariuszy Rzeczypospolitej Polskiej, 2018), 885 et seq.; Katarzyna Kopaczyńska-Pieczniak, “Status prawny zarządcy sukcesyjnego,” Przegląd Prawa Handlowego 12 (2018): 4 et seq.; Konrad Kopystyński, "Zarządca sukcesyjny jako przedsiębiorca," Przegląd Ustawodawstwa Gospodarczego 6 (2019): 18 et seq.; Paulina Pacek, "Wykonawca testamentu, a zarząd sukcesyjny przedsiębiorstwem osoby fizycznej - wybrane zagadnienia,” Rejent 6 (2019): 59 et seq.; Rafał Kapkowski and Marta Kaufmann, "Charakter prawny zarządcy sukcesyjnego na tle pokrewnych instytucji zarządu masą spadkową," Rejent 7 (2019): 54 et seq.

31 See the Act on the Central Registry and Information about Business Activity and Entrepreneur's Information Point of 6 March 2018, consolidated text, Journal of Laws 2020, item 2296, as amended. 
the succession from the deceased entrepreneur is effected under Polish law. On the other hand, when the law applicable to the succession is a foreign legal system, the appointment and exercise of succession administration may be based only on that foreign law. However, in Polish literature, a view has been expressed that the grounds for application of the Act in case of applying foreign law in succession matters can be sought in the provision of Art. 30 ESR. Its proponents argue that the provisions of the Act should apply regardless of whether the law applicable to the succession is Polish law or law of another country (Member State or a third country). They are of the opinion that the impact of the Act on the administration of an enterprise upon the entrepreneur's death means an impact on the enterprise's succession ${ }^{32}$.

Under Article $30 \mathrm{ESR}^{33}$, where the law of the State in which certain immovable property, certain enterprises or other special categories of assets are located contains special rules which, for economic, family or social considerations, impose restrictions concerning or affecting the succession in respect of those assets, those special rules shall apply to the succession in so far as, under the law of that State, they are applicable irrespective of the law applicable to the succession.

32 Such view is presented by Pazdan, "Zarząd sukcesyjny," 73-74; Pazdan, "O rozgraniczeniu statutów," 164 et seq. and Łukasz Żarnowiec, "Wpływ przepisów wymuszających swoje zastosowanie na rozstrzyganie spraw spadkowych pod rządami rozporządzenia Parlamentu Europejskiego i Rady (UE) nr 650/2012," Problemy Prawa Prywatnego Międzynarodowego 25 (2019): 54 et seq.

33 For more on Art. 30 ESR, see Gianluca Contaldi, "Special Rules Imposing Restrictions Concerning or Affecting the Succession in Respect of Certain Assets," in The EU Succession Regulation. A Commentary, eds. Alfonso-Luis Calvo Caravaca, Angelo Davi, and Heinz-Peter Mansel (Cambridge: Cambridge University Press, 2016), 430 et seq.; Maria Anna Zachariasiewicz, in Prawo Prywatne Międzynarodowe. Komentarz, ed. Maksymilian Pazdan (Warsaw: C.H. Beck, 2018), 1225 et seq.; Looschelders, in "Nomos Kommentar," 953 et seq.; Łukasz Żarnowiec, "Wpływ statutu," 304 et seq.; Idem, "Wpływ przepisów," 47 et seq.; Anna Machnikowska, in Unijne rozporządzenie spadkowe Nr 650/2012. Komentarz, ed. Mariusz Załucki (Warsaw: C.H. Beck, 2018), 233 et seq.; Margoński, in "Komentarze Prawa Prywatnego," 67 et seq.; Köhler, in "Internationales Erbrecht," 88 et seq. 
The cited provision overrides the principle of unity of the law applicable to the succession, as adopted for the purposes of ESR ${ }^{34}$. It is a special provision and, as such, requires strict interpretation ${ }^{35}$. This has been also confirmed in Recital $54^{36}$.

Application of Art. 30 ESR in relation to the succession of enterprises depends on cumulative fulfilment of three preconditions ${ }^{37}$ :

1. the enterprise is located in a country other than the country whose law is designated as the law applicable to the succession, regardless of whether the law applicable to the succession is determined by choice of law or using objective connecting factors. It is not necessary that the enterprise amounts to the entire estate or even its major part;

2. the law of that other county contains specific provisions imposing restrictions, on economic, family or social grounds, in respect of the succession or affecting the succession of an enterprise;

34 See Sarah Nietner, Internationaler Entscheidungseinklang im europäischen Kollisionsrecht (Tübingen: Mohr Siebeck, 2016), 125-126, 306 et seq.; Katarzyna Anna Dadańska, "O realizacji zasady jednolitości statutu spadkowego w świetle rozporządzenia nr 650/2012," Problemy Prawa Prywatnego Międzynarodowego 19 (2016): 75 et seq.; Köhler, in "Internationales Erbrecht," 88; Machnikowska, in "Unijne rozporządzenie," 236; Margoński, in "Komentarze Prawa Prywatnego," 68. See also the decision of the Polish Supreme Court of 11 March 2016, I CSK 64/15, Legalis.

35 See the Decision of Oberlandesgericht (German Higher Regional Court) Nürnberg of 27 October 2017, 15 W 1461/17, Zeitschrift für Erbrecht und Vermögensnachfolge (2018), 339; and Looschelders, in "Nomos Kommentar," 954; Maria Anna Zachariasiewicz, "Przepisy wymuszające swoje zastosowanie a statut spadkowy," in Nowe europejskie prawo spadkowe, eds. Maksymilian Pazdan and Jacek Górecki (Warsaw: Lex a Wolters Kluwer business, 2015), 330.

36 Lagarde, in "EU Regulation," 166. Academic authors indicate, as the most obvious example of applying Art. 30 ERS, the provisions on specific terms of succession of agricultural farms. See Jutta Müller-Lukoschek, Die neue EU-Erbrechtsverordnung (Bonn: Deutscher Notarverlag, 2013), 86; Maciej Mataczyński, "Przepisy ograniczające dziedziczenie na tle art. 30 rozporządzenia spadkowego," in Nowe europejskie prawo spadkowe, eds. Maksymilian Pazdan and Jacek Górecki (Warsaw: Lex a Wolters Kluwer business, 2015), 301 et seq.; Zachariasiewicz, "Przepisy wymuszające," 323; Contaldi, in "The EU Succession," 432 et seq. See also Pazdan, "Zarząd sukcesyjny," 74.

37 See Anatol Dutta, in Münchener Kommentar. Band 10, Internationales Privatrecht I, ed. Jan von Hein (München: C.H. Beck, 2015), 1570; Köhler, in "Internationales Erbrecht," 104 et seq. 
3. under the law of that other country, the specific provisions apply to the succession of an enterprise irrespective of the law applicable to the succession.

Establishment of the location of an enterprise in the discussed case should pose no major difficulties. The fact of an entrepreneur's registration in the Polish register entails that the entrepreneur operates in Poland. However, certain components of the enterprise may be situated outside Poland. This can relate to movable items (e.g. tractor units, machines, goods, raw materials for manufacture) but also to real estate or rights to real estate, as well as money or securities.

Under Art. 3(1) letter a ESR, "succession" means succession to the estate of a deceased person and covers all forms of transfer of assets, rights and obligations by reason of death, whether by way of a voluntary transfer under a disposition of property upon death or a transfer through intestate succession Therefore, succession is understood only as legal succession to a deceased natural person ${ }^{38}$. On the other hand, the concept does not cover the fate of the estate of such deceased natural person upon its transfer to the person's legal successors under statutory provisions or under a disposition mortis causa. In other words, administration of the estate cannot be treated as succession.

The provisions referred to in Art. 30 ESR must impose restrictions, on economic, family or social grounds, in respect of the succession or affect the succession of an enterprise. However, it is not clear what provisions exactly these could be ${ }^{39}$. This is the case since a considerable part of the provisions of succession law are motivated by family, social or economic grounds. Besides, the provisions of succession law on intestate succession, by their nature, limit succession from the deceased person since they eliminate from such succession a part of the deceased person's close persons and grant rights to the estate only to specific persons whose range is limited. One can only surmise that this refers to the provisions introducing specific terms of succession (legal succession) in respect of the assets

38 See Looschelders, in "Nomos Kommentar," 841.

39 See Mataczyński, "Przepisy ograniczające," 292-293. 
listed in Art 30 ESR $^{40}$. Such terms may refer both to their acquisition by legal successors (singular succession) or exclusion of certain persons from the succession of those assets, or imposition of additional requirements on the acquirers ${ }^{41}$.

Finally, it is necessary for the regime under Art. 30 ESR to apply that the special provisions restricting or affecting the succession apply regardless of the law applicable to the succession. This should follow from a clear wording of such provisions or use of interpretation methods other than textual interpretation ${ }^{42}$.

Referring the above remarks to the appointment of succession administration and its exercise, one should start with explaining that provisions of the Act do not impose restrictions on the succession of enterprises and do not affect such succession in any way. The Act does not interfere in this regard with the operation of the law applicable to the succession. Succession of an enterprise conducted in Poland by a deceased entrepreneur takes place exclusively under the provisions of law applicable to the succession, as established under the ESR regime. On the other hand, there should be no doubt that the purposes of the Act coincide with the purposes mentioned in Art. 30 ESR. Adoption of the Act was motivated by the need to maintain the unity of an enterprise and continuance of its operation despite death of the entrepreneur running the enterprise. Due to the above, the enterprise may still generate income to the deceased person's family, give jobs to the employees, pay public levies, etc ${ }^{43}$.

It is also important that it does not follow expressly from the provisions of the Act that the Act should apply irrespective of the law applicable to the succession ${ }^{44}$. In any case, appointment of succession administration as

40 See also Żarnowiec, "Wpływ statutu," 314-315. As pointed out by Zachariasiewicz, "Przepisy wymuszające," 333, the grounds listed in Art. 30 ESR are so vague that it would be difficult to treat the catalogue otherwise than as reference to the idea of protecting public order.

41 See Machnikowska, in "Unijne rozporządzenie," 235; Köhler, in "Internationales Erbrecht," 90.

42 See Mataczyński, "Przepisy ograniczające," 293-294.

43 See Bieluk, "Ustawa o zarządzie," 2 et seq.

44 Otherwise in Pazdan, "Zarząd sukcesyjny," 73 and Żarnowiec, "Wpływ przepisów," 55, who derive from Art. 1 of the Act an obligation of its application irrespective of 
such is not compulsory in Poland. The provisions on succession administration do not require appointment of a succession administrator when the estate left by the deceased person includes an enterprise. In this regard, they are not imperative (mandatory) provisions. Appointment of a succession administrator after the death of an entrepreneur depends only on the decision of the entrepreneur's legal successors (owners of the enterprise in succession). Strict interpretation of Art. 30 ESR (having regard to its special nature) does not allow to extend its application to non-mandatory rules.

In consequence, it must be concluded that Art. 30 ESR does not justify the application of the Act and does not provide grounds to appoint succession administration as provided for in the Act if the law applicable to the entirety of succession matters relating to the estate left by a deceased entrepreneur is not Polish law. Administration of the estate is covered by the domain of lex successionis, as expressly stated in Art. 23 letter $\mathrm{f}$ ESR. Succession administration, as regulated in the Act, does not restrict the succession of enterprises and does not affect the succession of enterprises in the understanding of ESR. It does not modify the terms of transfer of the enterprise as a result of the entrepreneur's death to the entrepreneur's legal successors ("owners of the enterprise in succession" in the understanding of the Act). It refers only to the administration of an enterprise which, as a result of succession has been passed on to the legal successors of the deceased entrepreneur under provisions of the law applicable to the succession.

Appointment of succession administration (including of a succession administrator) is governed by the law applicable to the succession regardless if made prior to or upon the entrepreneur's death. In this regard, the Succession Regulation does not provide for a possibility of choice of law. On the other hand, by choice of law under Art. 22 ESR, an entrepreneur may submit the total of matters relating to the entrepreneur's succession to Polish law and, in the same way, open up the possibility to effectively appoint a succession administrator even when Polish law would not be applicable in this respect under Art. $21 \mathrm{ESR}^{45}$.

whether the law applicable to the succession is Polish law or law of another country.

45 For more on the law applicable to the appointment of a succession administrator and legal acts performed by succession administrator, see also Jacek Górecki, "Prawo 


\section{CONCLUSIONS}

Administration of the succession estate upon the deceased person's death is governed by the law applicable to the entirety of succession matters (lex successionis), determined under Arts. 21 and 22 ESR. In this context, it does not matter who administrates the estate. In situations specified in Art 29 ESR, administration of the estate may be partly based on the provisions applicable in the country in which the court examining the succession case (lex fori) adjudicates, as long as the court has jurisdiction under the ESR.

Succession administration, known in Poland since 2018, may be appointed only when the law applicable to the total of matters relating to the succession left by an entrepreneur conducting business activities in Poland is Polish law. Article 30 ERS does not provide basis for the application of succession administration, as regulated in Polish law, when the law applicable to the succession is foreign law. The provisions on succession administration do not impose any restrictions on the succession of enterprises and do not affect such succession. In the same way, one of the preconditions to the application of Art. 30 ESR is not fulfilled. As special provision, that Article may not be interpreted extensively.

\section{REFERENCES}

Bieluk, Jerzy. Ustawa o zarządzie sukcesyjnym przedsiębiorstwem osoby fizycznej. Komentarz. Warsaw: C.H. Beck, 2019.

Biernat, Jakub. "Artykuł 59 [Przyjmowanie dokumentów urzędowych]." In Unijne rozporzadzenie spadkowe $\mathrm{Nr}$ 650/2012. Komentarz, edited by Mariusz Załucki, 326-332. Warsaw: C.H. Beck, 2018.

Blicharz, Rafał. Zarząd sukcesyjny przedsiębiorstwem w spadku. Warsaw: Difin, 2019.

Budzikiewicz, Christine. "Effects of the Certificate." In The EU Succession Regulation. A Commentary, edited by Alfonso-Luis Calvo Caravaca, Angelo Davi, and Heinz-Peter Mansel, 769-794. Cambridge: Cambridge University Press, 2016.

właściwe dla czynności prawnych związanych z zarządem sukcesyjnym," Problemy Prawa Prywatnego Międzynarodowego 26 (2020): 96 et seq. 
Contaldi, Gianluca. "Special Rules on the Appointment and Powers of an Administrator of the Estate in Certain Situations." In The EU Succession Regulation. A Commentary, edited by Alfonso-Luis Calvo Caravaca, Angelo Davi, and Heinz-Peter Mansel, 417-429. Cambridge: Cambridge University Press, 2016.

Contaldi, Gianluca. "Special Rules Imposing Restrictions Concerning or Affecting the Succession in Respect of Certain Assets." In The EU Succession Regulation. A Commentary, edited by Alfonso-Luis Calvo Caravaca, Angelo Davi, and Heinz-Peter Mansel, 430-441. Cambridge: Cambridge University Press, 2016.

Dadańska, Katarzyna Anna. "O realizacji zasady jednolitości statutu spadkowego w świetle rozporządzenia nr 650/2012.” Problemy Prawa Prywatnego Międzynarodowego 19 (2016): 65-87.

D’Alessandro, Elena. "Staying of Recognition Proceedings." In The EU Succession Regulation. A Commentary, edited by Alfonso-Luis Calvo Caravaca, Angelo Davi, and Heinz-Peter Mansel, 561-566. Cambridge: Cambridge University Press, 2016.

Dutta, Anatol. "Art. 30 EuErbVO." In Münchener Kommentar. Band 10, Internationales Privatrecht I, edited by Jan von Hein, 1569-1572. München: C.H. Beck, 2015.

Fischer-Czermak, Constanze. "Anwendbares Recht." In Europäische Erbrechtsverordnung, edited by Martin Schauer, and Elisabeth Scheuba, 43-55. Wien: Manz, 2012.

Górecki, Jacek. Europejskie poświadczenie spadkowe - nowy sposób potwierdzania praw do majątku spadkowego, Rejent 9 (2015): 9-28.

Górecki, Jacek. "Prawo właściwe dla czynności prawnych związanych z zarządem sukcesyjnym." Problemy Prawa Prywatnego Międzynarodowego 26 (2020): 189-208.

Kapkowski, Rafał, and Marta Kaufmann. "Charakter prawny zarządcy sukcesyjnego na tle pokrewnych instytucji zarządu masą spadkową." Rejent 7 (2019): 54-88.

Kopaczyńska-Pieczniak, Katarzyna. "Status prawny zarządcy sukcesyjnego.” Przeglad Prawa Handlowego 12 (2018): 4-11.

Kopystyński, Konrad. "Zarządca sukcesyjny jako przedsiębiorca.” Przeglad Ustawodawstwa Gospodarczego 6 (2019): 18-24.

Kozioł, Agata. "System administracji spadku w porządkach prawnych państw kręgu anglosaskiego." Rejent 2 (2006): 119-132.

Köhler, Andreas. “EuErbVO.” In Internationales Erbrecht, edited by Walter Gierl, Andreas Köhler, Ludwig Kroiß, and Harald Wilsch, 17-149. Baden Baden: Nomos, 2020. 
Kreße, Bernhard. "Creation of a European Certificate of Succession." In The EU Succession Regulation. A Commentary, edited by Alfonso-Luis Calvo Caravaca, Angelo Davi, and Heinz-Peter Mansel, 673-685. Cambridge: Cambridge University Press, 2016.

Kreße, Bernhard. "Purpose of the Certificate." In The EU Succession Regulation. A Commentary, edited by Alfonso-Luis Calvo Caravaca, Angelo Davi, and Heinz-Peter Mansel, 686-698. Cambridge: Cambridge University Press, 2016. Lagarde, Paul. "Applicable Law." In EU Regulation on Succession and Wills. Commentary, edited by Ulf Bergquist, Domenico Damascelli, Richard Frimson, Paul Lagarde, Felix Odersky, and Barbara Reinhartz, 119-182. Köln: Verlag Dr. Otto Schmidt KG, 2015.

Looschelders, Dirk. In Nomos Kommentar. Band 6. Rom-Verordnungen, edited by Rainer Hüßtege, and Heinz-Peter Mansel, 806-847, 910-987. Baden Baden: Nomos, 2015.

Machnikowska, Anna. "Artykuł 30 [Szczególne przepisy nakładające ograniczenia dotyczące dziedziczenia lub wpływające na nie w odniesieniu do niektórych składników majątku]." In Unijne rozporządzenie spadkowe Nr 650/2012. Komentarz, edited by Mariusz Załucki, 229-241. Warsaw: C.H. Beck, 2018.

Mansel, Heinz-Peter. "Acceptance of Authentic Instruments." In The EU Succession Regulation. A Commentary, edited by Alfonso-Luis Calvo Caravaca, Angelo Davi, and Heinz-Peter Mansel, 625-663. Cambridge: Cambridge University Press, 2016.

Margoński, Marcin. "Artykuł 29 [Szczególne przepisy dotyczące wyznaczania zarządcy spadku oraz jego uprawnienia w niektórych sytuacjach]." In Komentarze Prawa Prywatnego, T. VI B, Prawo i postępowanie spadkowe. Komentarz, edited by Konrad Osajda, 64-67. Warsaw: C.H. Beck, 2018.

Mataczyński, Maciej. "Przepisy ograniczające dziedziczenie na tle art. 30 rozporządzenia spadkowego." In Nowe europejskie prawo spadkowe, edited by Maksymilian Pazdan, and Jacek Górecki, 282-315. Warsaw: Lex a Wolters Kluwer business, 2015.

Müller-Lukoschek, Jutta. Die neue EU-Erbrechtsverordnung. Bonn: Deutscher Notarverlag, 2013.

Nietner, Sarah. Internationaler Entscheidungseinklang im europäischen Kollisionsrecht. Tübingen: Mohr Siebeck, 2016.

Nordmeier, Carl Friedrich. "Artikel 69 Wirkungen des Zeugnisses." In Nomos Kommentar. Band 6. Rom-Verordnungen, edited by Rainer Hüßtege, and Heinz-Peter Mansel, 1079-1086. Baden Baden: Nomos, 2015.

Osajda, Konrad. Ustanowienie spadkobiercy $w$ testamencie $w$ systemach prawnych common law i civil law. Warsaw: C.H. Beck, 2009. 
Pacek, Paulina. "Wykonawca testamentu, a zarząd sukcesyjny przedsiębiorstwem osoby fizycznej - wybrane zagadnienia." Rejent 6 (2019): 59-83.

Pazdan, Maksymilian. In Prawo prywatne międzynarodowe. Komentarz, edited by Maksymilian Pazdan, 1162-1189. Warsaw: C.H. Beck, 2018.

Pazdan, Maksymilian. "Zarządca sukcesyjny a wykonawca testamentu." In Ius est ars boni et aequi. Ksiega pamiątkowa dedykowana Profesorowi Józefowi Frąckowiakowi, edited by Anna Dańko-Roesler, Marek Leśniak, Maciej Skory, and Bogusław Sołtys, 885-894. Wrocław: Stowarzyszenie Notariuszy Rzeczypospolitej Polskiej, 2018.

Pazdan, Maksymilian. "Zarząd sukcesyjny - aspekty kolizyjnoprawne.” In Prawo handlowe. Między teoria, praktyka a orzecznictwem. Ksiegga jubileuszowa dedykowana Profesorowi Januszowi A. Strzępce, edited by Ewa Zielińska, Piotr Pinior, Paweł Relidzyński, Wojciech Wyrzykowski, and Mateusz Żaba, 67-77. Warsaw: C.H. Beck, 2019.

Pazdan, Maksymilian. "O rozgraniczeniu statutów i wsysaniu regulacji prawnej (na przykładzie prawa stosowanego do oceny różnych aspektów powołania i funkcjonowania wykonawcy testamentu i zarządcy sukcesyjnego przedsiębiorstwem).” Problemy Prawa Prywatnego Międzynarodowego 27 (2021): 159-177.

Reinhartz, Barbara. "European Certificate of Succession." In EU Regulation on Succession and Wills. Commentary, edited by Ulf Bergquist, Domenico Damascelli, Richard Frimson, Paul Lagarde, Felix Odersky, and Barbara Reinhartz, 245-298. Köln: Verlag Dr. Otto Schmidt KG, 2015.

Stec, Piotr. "Artykuł 29 [Szczególne przepisy dotyczące wyznaczania zarządcy spadku oraz jego uprawnienia w niektórych sytuacjach]." In Unijne rozporzadzenie spadkowe $\mathrm{Nr}$ 650/2012, edited by Mariusz Załucki, 223-229. Warsaw: C.H. Beck, 2018.

Szczurowski, Tomasz. "Zarząd sukcesyjny przedsiębiorstwem w spadku.” Przegląd Ustawodawstwa Gospodarczego 11 (2018): 31-36.

Wieczorek, Anna. "Ustalenie prawa właściwego w świetle rozporządzenia spadkowego nr 650/2012." Problemy Prawa Prywatnego Międzynarodowego 21 (2017): 69-93.

Zachariasiewicz, Maria Anna. "Przepisy wymuszające swoje zastosowanie a statut spadkowy." In Nowe europejskie prawo spadkowe, edited by Maksymilian Pazdan, and Jacek Górecki, 316-339. Warsaw: Lex a Wolters Kluwer business, 2015.

Zachariasiewicz, Maria Anna. "Artykuł 30 [Szczególe przepisy nakładające ograniczenia dotyczące dziedziczenia lub wpływające na nie w odniesieniu do niektórych składników majątku]." In Prawo prywatne międzynarodowe. 
Komentarz, edited by Maksymilian Pazdan, 1225-1234. Warsaw: C.H. Beck, 2018.

Załucki, Mariusz. "Artykuł 62 [Ustanowienie europejskiego poświadczenia spadkowego]." In Unijne rozporzadzenie spadkowe Nr 650/2012. Komentarz, edited by Mariusz Załucki, 334-340. Warsaw: C.H. Beck, 2018.

Żarnowiec, Łukasz. Wptyw statutu rzeczowego na rozstrzyganie spraw spadkowych na styku statutów. Warsaw: C.H. Beck, 2018.

Żarnowiec, Łukasz. "Wpływ przepisów wymuszających swoje zastosowanie na rozstrzyganie spraw spadkowych pod rządami rozporządzenia Parlamentu Europejskiego i Rady (UE) nr 650/2012." Problemy Prawa Prywatnego Międzynarodowego 25 (2019): 43-65. 
